4. Clayton DA, Browning MD. Deficits in the expression of the NR2B subunit in the hippocampus of aged Fisher 344 rats. Neurobiol Aging 2001:22:165-168.

5. Nihei MK, Desmond NL, McGlothan JL, Kuhlmann AC, Guilarte TR. $N$-methyl-D-aspartate receptor subunit changes are associated with lead-induced deficits of long-term potentiation and spatial learning. Neuroscience 2000;99:233-242.

6. Schwartzkroin PA, Walsh CA. Cortical malformations and epilepsy. Ment Retard Dev Disabil Res Rev 2000;6:268-280.

7. Mischel P, Nguyen L, Vinters H. Cerebral cortical dysplasia associated with pediatric epilepsy. Review of neuropathologic features and proposal for grading system J Neuropathol Exp Neurol 1995;54:137153.
8. Crino PB, Eberwine J. Cellular and molecular basis of cerebral dysgenesis. J Neurosci Res 1997;50:907-916.

9. Rorke L. A perspective: the role of disordered genetic control of neurogenesis in the pathogenesis of migration disorders. J Neuropathol Exp Neurol 1994;53:105-117.

10. Jacobs KM, Kharazia VN, Prince DA. Mechanisms underlying epileptogenesis in cortical malformations. Epilepsy Res 1999;36:165-188.

11. Avoli M, Bernasconi A, Mattia D, Olivier A, Hwa GG. Epileptiform discharges in the human dysplastic neocortex: in vitro physiology and pharmacology. Ann Neurol 1999;46:816-826.

12. Luhmann HJ, Karpuk N, Qu M, Zilles K. Characterization of neuronal migration disorders in neocortical structures. II. Intracellular in vitro recordings. J Neurophysiol 1998;80:92-102.

\title{
Neuro/mages
}
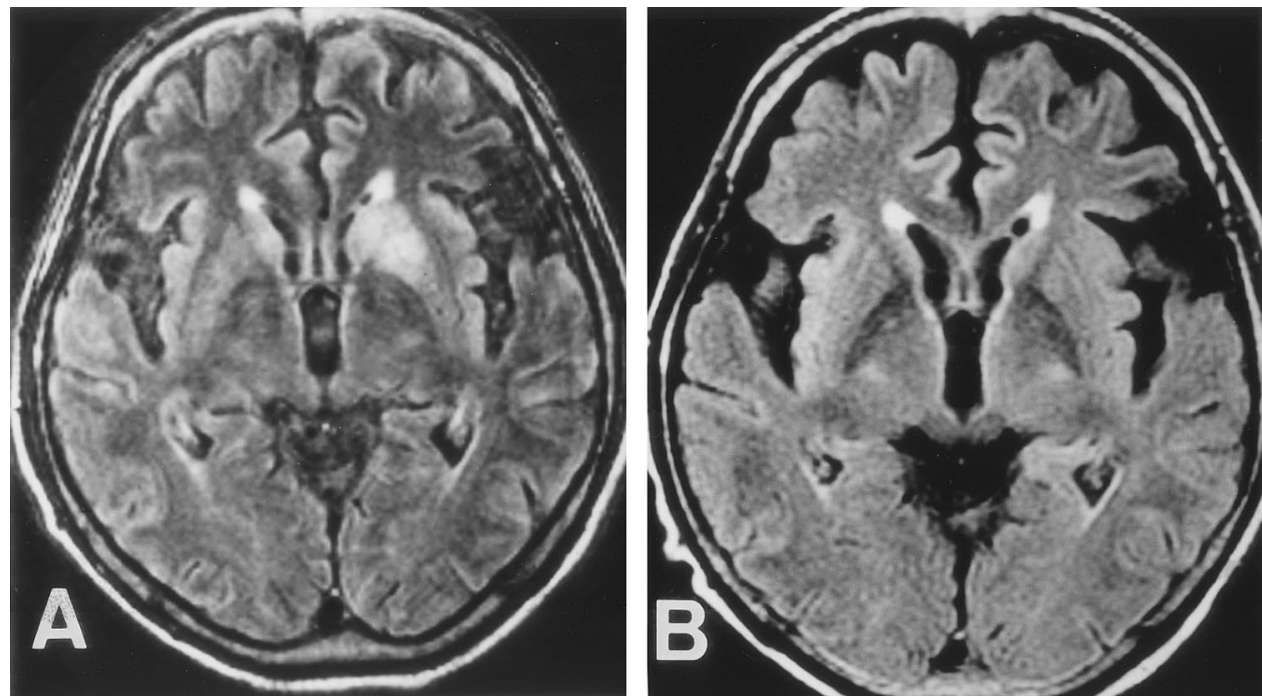

Figure. Axial fluid-attenuated inversion recovery (FLAIR) brain MRI showed hyperintense signals in bilateral caudate and the left putamen nuclei (A), but no medial temporal lobe abnormalities. No abnormal contrast enhancement was observed (not shown). After six cycles of chemotherapy (carboplatin and etoposide), MRI revealed complete disappearance of the brain lesions (B).

\section{Paraneoplastic striatal encephalitis}

T. Oguma, MD, H. Kobayashi, MD, PhD, S. Katada, MD,

O. Onodera, MD, PhD, K. Tanaka, MD, S. Tsuji, MD, PhD,

T. Uno, MD, T. Ishida, MD, H. Kagamu, MD, F. Gejyo, MD, PhD,

Niigata, Japan; M. Motomura, $M D$,

Nagasaki, Japan

A 56-year-old man presented with abulia, muscle weakness, and hyporeflexia. The chest CT showed mediastinal lymphadenopathy. Serum titers of anti-P/Q-type-voltagegated calcium channel, pro-gastrin-releasing-peptide, and anti-Hu antibody were elevated. MRI demonstrated hyperintense signals in the basal ganglia (figure). An EEG showed no evidence of seizures. He was diagnosed with paraneoplastic syndrome with small cell lung cancer (stage IIIA, limited disease). After chemotherapy, he had complete response and his neurologic deficits improved. The MRI lesions disappeared (see the figure). Selective involvement of the basal ganglia in paraneoplastic encephalitis is rare. ${ }^{1}$ Chorea, reported in other cases, ${ }^{1}$ was not observed but abulia was present in our case. ${ }^{2}$

1. Tani T, Piao Y, Mori S, et al. Chorea resulting from paraneoplastic striatal encephalitis. J Neurol Neurosurg Psychiatry 2000;69:512-515.

2. Kumral E, Evyapan D, Balkir K. Acute caudate vascular lesions. Stroke 1999;30:100-108. 


\section{Neurology}

\section{Paraneoplastic striatal encephalitis}

T. Oguma, H. Kobayashi, S. Katada, et al.

Neurology 2001;57;2326

DOI 10.1212/WNL.57.12.2326

\section{This information is current as of December 26, 2001}

\section{Updated Information \& Services}

\section{References}

Subspecialty Collections

Permissions \& Licensing

Reprints including high resolution figures, can be found at: http://n.neurology.org/content/57/12/2326.full

This article cites 2 articles, 2 of which you can access for free at: http://n.neurology.org/content/57/12/2326.full\#ref-list-1

This article, along with others on similar topics, appears in the following collection(s):

\section{MRI}

http://n.neurology.org/cgi/collection/mri

Paraneoplastic syndrome

http://n.neurology.org/cgi/collection/paraneoplastic_syndrome

Information about reproducing this article in parts (figures,tables) or in its entirety can be found online at:

http://www.neurology.org/about/about_the_journal\#permissions

Information about ordering reprints can be found online: http://n.neurology.org/subscribers/advertise

Neurology ${ }^{\circledR}$ is the official journal of the American Academy of Neurology. Published continuously since 1951, it is now a weekly with 48 issues per year. Copyright . All rights reserved. Print ISSN: 0028-3878.

Online ISSN: 1526-632X.

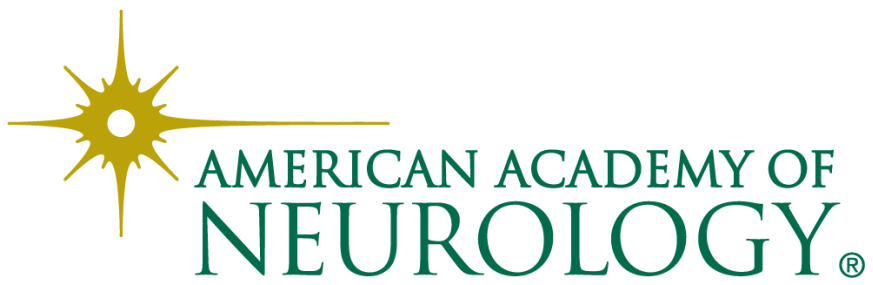

